Meta

Journal des traducteurs

Translators' Journal

\title{
Legal Interpreting in Canada's Eastern Arctic
}

\section{Atsainak Akeeshoo}

Volume 38, numéro 1, mars 1993

La traduction et l'interprétation dans le nord du Canada

Translation and Interpretation in Northen Canada

URI : https://id.erudit.org/iderudit/001866ar

DOI : https://doi.org/10.7202/001866ar

Aller au sommaire du numéro

Éditeur(s)

Les Presses de l'Université de Montréal

ISSN

0026-0452 (imprimé)

1492-1421 (numérique)

Découvrir la revue

Citer cet article

Akeeshoo, A. (1993). Legal Interpreting in Canada's Eastern Arctic. Meta, 38(1), 35-37. https://doi.org/10.7202/001866ar

\section{Résumé de l'article}

On trace les grandes lignes de l'histoire du système législatif canadien dans l'est de l'Artique depuis le début du siècle, en insistant sur la période d'après 1945 On traite des difficultés auxquelles les interprètes juridiques de cette région ont dû faire face et des défis qu'ils ont relevés. On identifie les problèmes engendrés du fait que les concepts fondamentaux de la justice indo-européenne étaient d'abord tout à fait étrangers aux ¡nuit. On discute aussi des problèmes liés aux différences lexicales et syntaxiques entre l'inuktitut et l'anglais. On souligne l'alourdissement de la tâche des interprètes depuis l'admission des jurés unilingues au sein des jury en 1989 et on explique comment on arrive à composer avec cette situation. 


\title{
LEGAL INTERPRETING IN CANADA'S EASTERN ARCTIC
}

\author{
ATSAINAK AKEESHOO \\ G.N.W.T. Culture and Communications, \\ Iqaluit, Northwest Territories, Canada
}

\begin{abstract}
Résumé
On trace les grandes lignes de l'histoire du système législatif canadien dans l'est de l'Artique depuis le début du siècle, en insistant sur la période d'après 1945. On traite des difficultés auxquelles les interprètes juridiques de cette région ont dû faire face et des défis $q u ' i l s$ ont relevés. On identifie les problèmes engendrés du fait que les concepts fondamentaux de la justice indo-européenne étaient d'abord tout à fait étrangers aux Inuit. On discute aussi des problèmes liés aux différences lexicales et syntaxiques entre l'inuktitut et l'anglais. On souligne l'alourdissement de la tâche des interprètes depuis l'admission des jurés unilingues au sein des jury en 1989 et on explique comment on arrive à composer avec cette situation.
\end{abstract}

\begin{abstract}
This paper outlines the historical development of the Canadian legal system in the Eastern Arctic since the turn of the century, particularly after the Second World War. It discusses the challenges and difficulties faced by legal interpreters in situations where fundamental concepts of Indo-European justice were initially foreign to the Inuit. It explores some of the problems created by the differences between the lexicon and syntax of Inuktitut and English. It describes how the already difficult task of legal interpreting has been compounded by the recent change in the Jury Act of the NWT, in September, 1989, allowing unilingual jurors to sit on juries and how this situation has been handled.
\end{abstract}

Inuit contact with Canadian legal system began in 1903 when the Government of Canada began to launch yearly expeditions by the Royal Northwest Mounted Police (renamed Royal Canadian Mounted Police in 1920) to affirm Canadian sovereignty in the Arctic. A system of Royal Canadian Mounted Police detachments was established in the Arctic shortly thereafter.

Between 1903 and 1921, Canadian Inuit were virtual wards of the Royal Canadian Mounted Police, who, in addition to introducing the rule of Canadian law, acted as justices of the peace and administered postal, medical and welfare services.

After World War I, the Royal Canadian Mounted Police began charging Inuit under the Criminal Code, mostly for serious offenses like murder. Court parties, including judges, counsel and so on, would travel to Arctic locations in the summer on annual supply ships.

In 1921 when three Inuit from Pond Inlet were being tried for the homicide of an independent fur trader named Robert Janes, a Royal Canadian Mounted Police staffsergeant reported that the accused and several Inuit witnesses displayed little comprehension of the proceedings and made statements despite being given the usual statutory warnings.

Throughout the 1920's and 1930's, other Royal Canadian Mounted Police officers reported similar difficulties in carrying out their duties due to the lack of able interpreters. Because of their position as the sole representatives of the Canadian Government living in the Arctic on a year-round basis, they found themselves saddled with the difficult task 
of having to explain the Canadian legal system to the Inuit. In 1931, one officer on patrol in the Keewatin reported that the natives were under the impression that the police killed any native who had committed a wrong.

Until 1955, less serious offenses in the Northwest Territories were dealt with by stipendiary magistrates (lawyers who functioned as quasi-judges) and justices of the peace (usually Royal Canadian Mounted Police officers or Hudson Bay Company officials).

In 1955, the Territorial Court (re-named the Supreme Court of the Northwest Territories in 1972) was established with Mr. Justice J.H. Sissons as its first justice. At the same time, a new Justice of the Peace system was established with community members gradually replacing Royal Canadian Mounted Police officers and Hudson's Bay Company officials. After 1970, Royal Canadian Mounted Police officers could no longer serve as Justices of the Peace. A magistrate's court, now called the Territorial Court, was created with jurisdiction over all summary conviction offenses and minor indictable offenses, as well as the responsibility for conducting preliminary inquiries for indictable offenses to be heard by the Supreme Court.

Between 1955 and 1966, Justice Sissons often angered federal officials with his insistence on the independence of the judiciary and by the extent to which he recognized native culture and customary law in his decisions.

In 1971, a legal aid scheme was developed by the territorial and federal governments.

In 1973, the territorial government's Interpreter Corps was formed. The first group of trainees received some instruction in court interpreting, but this was quite sketchy.

In 1975, a legal aid clinic, Maligannik Tukisiniakvik, was established in Iqaluit in the Eastern Arctic, under a board made up of local Inuit. This office now provides legal services throughout the Baffin region, with lawyers in Pond Inlet and Yellowknife.

In 1987 a resident Territorial Court judge was appointed to serve the Baffin region of the Eastern Arctic from Iqaluit. The region had previously been served by circuit courts flying out of Yellowknife. At the same time, the federal Department of Justice established a Crown Prosecutor's office in Iqaluit.

A legal interpreter's training program was set up by the Department of Justice in Yellowknife in 1987 under the direction of Ms. Betty Harnum to specifically deal with the training of legal interpreters for the court system. The role of legal interpreting in the Territories is filled with challenges and difficulties. Even fundamental concepts of IndoEuropean justice were foreign to the Inuit. The concepts of guilty and not guilty were understood quite differently by Inuit people. People pled guilty in court if they felt remorse about what had occurred. Because of this, a not guilty plea was almost unheard of. This created acute demands on the interpreter who had not only to understand the legal system, but to provide culturally relevant terminology so that Inuit really did have enough understanding of the law so that their fundamental rights were protected. Even today the closest equivalent to the English concepts of guilty and not guilty are translated as pasijaksaujunga which literally translates as "I should be blame" and pasijaksaunngittunga, "I should not be blame." The concept of innocent is translated as pirajaksimanngittuq which literally translates as "he has not committed a crime."

Some terms must be stated explicitly in Inuktitut for a translation to occur. For example, assault has to be specified as there is no general term. Assault by touching would be translated as attuqsijuq; assault by punching is paitaksijuq; assault by slapping, patiksijuq; assault with a gun is translated as qukiutiqaqtuni.

Both negative questions and negative tag questions cause difficulty while interpreting. Traditionally, negative questions were always answered in the affirmative:

You were not in the house the night of the murder, right?

Iglumilaunngittutinai inuartautillugu? 
as were tag questions such as:

You struck him on the head, didn't you?

Niqqunngaguut paitalaurtaitnai?

However, great confusion occurs with some speakers who have been influenced by the English negation system who answer these questions in the negative. This causes great ambiguity in communication and may necessitate the interpreter asking for clarification by asking the speaker to expand the answer.

Kinship terms are also difficult to translate. When talking about the term sister in English there are three terms in Inuktitut. For a woman there are two terms for sister, angajuq for older sister and nukaq for younger sister. Men use only one term najaq, which is also the term used for female cousin by a man. The lack of exact equivalency runs throughout the kinship system.

Although major efforts have been under-way over the last few years to standardize technical legal vocabulary, major difficulties often occur in non-technical vocabulary due to dialect variations of Inuktitut. (There are four main dialects and sixteen sub-dialects of Inukitut). For example, aliasuktunga is translated as "I am scared" in the Baffin and Keewatin areas of the Eastern Arctic, but "I am joyful" in Northern Quebec.

As new technology was introduced in this century, different words were coined in different dialect areas for these new objects. For example, the word for airplane is qangatajuuq "the thing that flies", in Baffin but tingmisuuq, "the thing with wings", in the Keewatin. An interpreter has to be very familiar with dialectal variations to ensure an accurate interpretation.

Non-verbal responses for yes and no differ significantly from southern Canadian responses. In Inuktitut raising of the eyebrows is the equivalent of nodding of the head and wrinkling the nose indicates the equivalent of shaking the head. This necessitates the judges asking for a verbal response. Recently, however, some judges familiar with northern native culture have accepted these responses, particularly from children as an attempt to lessen the stress put on the child.

Adding to the already difficult task of the legal interpreter, has been the recent change in the Jury Act which was passed in September of 1989 in which unilingual native people were given the right to sit on juries in the Northwest Territories.

Before the passage of this Act, some court procedures, upon the agreement of the parties involved, were not interpreted, such as the charge to the jury; now all procedures must be interpreted in totality.

This change has also created a greater demand for interpreters as more are needed; one for the court and at least one more for the jury. Court procedures are interpreted consecutively and the skills required are different than those needed for jury interpreters which are sight translation, consecutive and simultaneous interpretation.

Although these changes have created extra burdens for the legal interpreter over the short term, over the long term, they will enable Inuit to participate more fully in a system which has long been perceived as foreign. It will enable native people to be tried by their peers, a fundamental principle of the judicial system which has been denied Inuit over the years, and will help to protect basic rights and freedoms. 